\title{
深層試 錐
}

早 正已*

深層試錐（deep drilling）については前回のシンポジウムに報告しなかったので，これが初めてである。 深い井戸をほるのは大変魅力的なととにちがいない。何故ならば，それによって直接に地殼内部（およ びマントル上部）の様子を肌にふれてしらべることができるから。従ってアメリカ，ソ連等においてはす でにこの試錐に手をつけている。しかしそれには莫大な費用を投じなければならない。それゆえ，慎重に 計画をたて，投資に見合うだけの成果が得られるよう心がけることが必要である。

ここには采ず深層試錐のもつ意義，ついで作孔技術の問題点，孔井内での測定，おしまいに試錐位置の 選定ならびに日本の深層試錐計画について述べよう。

深い井戸をほることは色々の意味をもっている。すでに地球物理, 地球化学, 地質学的な方法によって 得られている地殼乃至はマントル上部の知識を, 直接的な方法で確かめ, またそ机に新しい知識を加えう ることについては言を俟たない。それ以外に，ほる為にまず試錐技術が進歩するであるう。なお，坑井内 部での種々の測定技術そのものも発展することが期待される。さらに坑井が仕上がった後に坑井内部に地 震計その他の計測器を入れて半永久的にこれを利用することも当然考光られるの゙ある。しかし日本の実 情からすれば，ほられるのは技そらく一本であるう。 （浅い井戸をいくつもほることは，今の場合不経済 である。）そらだとすればこの一本の井戸を充分効 果的に生かせる為には, あらかじめその周辺地域を 充分しらべておくことが大切である。

以上が深層試錐のもつ意義であるが，次に作孔技 術上の問題点に移ろう。

ひと口に深い井戸をほるといっても，実際にはこ れは大へえな事柄である。

すでに石油をとり出す為の井戸にはかなり深いむ のがある。こころみに 1940 年から現在迄のソ連, アメリカでの深井戸のくっ進状況を図示してみた。 しかし，こ机らは石油を目標とするものであって， UMPの場合には更に難しい点が加わるのである。

それはひと口にいえば石油の場合よりはるかに硬 い地層をほらなけ秃ばならないということである。 その他に場合によってはかなり高温度のところをほ るということにもなる。

硬い地層で高温, 高圧のもとで法坑井内の試錐機 先端のダイヤモンドビットも急激に掘さく能力が衰 えると共に, 坑井内の循環泥水の性質も変化する為, あらかじめ，充分これらに対する技術的研究を行な っておかなければならない。また, 試錐途中でパイ プが切れたり，つなぎ目がゆるんで抜けたり，試錐

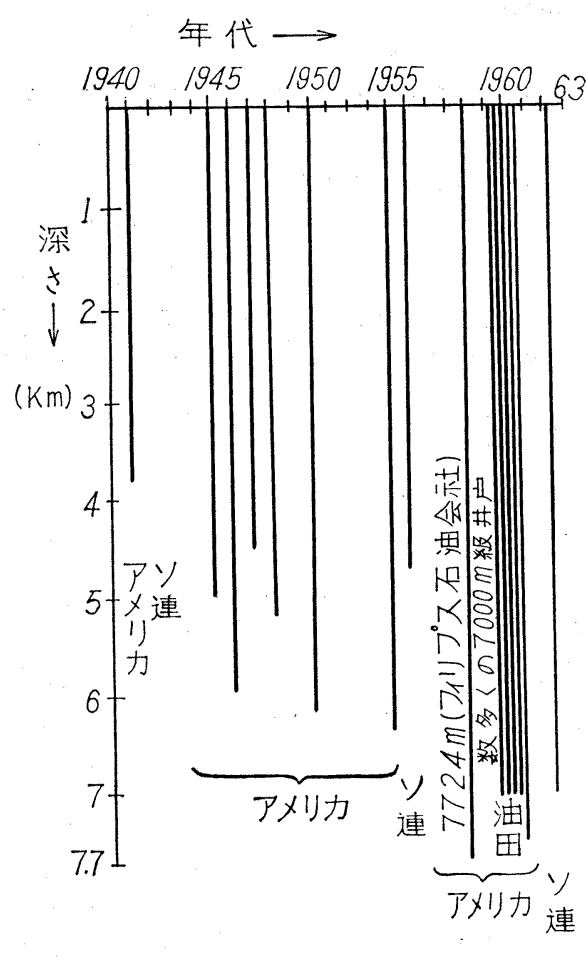

$*$ 地質調查所 
泥壁がくずれたり，更には孔まがりのことなどもしっかりと対策を講じておかなければならない。UMP の場合は all coring で地下梁部のコァーを切り取ってもってくるのであるから，このための技術，作業も 並大抵のことではない。また一本ほるのにかなりの月数（後に出てくるが日本の場合，4,500 m 深さとし て 1 年半) を要するので，UMPでやる場合，スタートの時期をよく検討しておかなければならない。 作孔技術の問題点はこの位にして，坑井の測定につけて述べよう。

今もしるしたような地下深部から得られるコァーについての地質学的, 岩石学鉣物学的な研究について は，当然なされるべきこととして説明の要もないであろうが，その他に地球物理学，地球化学の方からの しらべがなされなければならない。まず地球物理の方には次のようなるのがある。

$\bigcirc$ 電気検層……比抵抗, 自然電位, micro, latero-log, induction $\log$ などがあり,これらの測定によっ

て地層の電気的性質，われ目や透水性地層などの状態を知ることができる。

$\bigcirc$ 放射能検層……自然の $r$ 線を測定するものと, 人工放射線を利用するもの（ $r-\gamma$ 密度検層, 中性子 検層，塩分検層）などあり。たとえば自然の $r$ 線測定によっては，(水成岩にはごく微量であるが 放射性鉣物が含まれており，頁岩，砂岩などの岩質によりその含有量が多少異なるので）地層の識 別，対比ができる。また，r線が物質中を透過する場合，コンプトン散乱が反応の主過程となるの で，r-r の場合は，この反応を利用して地層の密度が測定できる。

音波検層……Sonic log, synthetic seismogram の利用。Sonic log の方は地層中を伝播する弾性波速 度を直接測定できる。これによつて heterogeneous, anistropic な地層の性質も知ることができる。 Synthetic seismogram の方は地下の弾性波速度分布を知った上，反射係数を利用して，逆に人工 的な地震記録をつくり，実際の人工地震波記録と比較して正確，詳細な地下構造を知るのに役立つ。

$\bigcirc$ 温度検層……サーミスターなどの利用により坑井内の温度を記録する。地殼の放熱流量测定にも大切 な資料を提供できる。

$\bigcirc$ Formation tester.......地層圧力の測定を行なう。温度検層と formation test は単に坑井内の温度, 圧力を測定するのみならず，弾性波速度，電気的性質などが温度，圧力にょり变化する関係も直接 に知ることができる。

○地磁気の測定……坑井内に磁力計をおろして直接に地磁気の測定を行なう。

Gun perforator, side wall sampling……地層内のコァーを坑壁より抜き取ってくる方法。ワイヤー で砲身につながれたコァー採集弾丸を砲身に装填し，必要な深さで火薬の力で坑壁に打ち込み，そ の後で砲身を上に引っ張り，採集弾丸を地層より抜き取ってくる。

以上は地球物理的な方法である。これらと同様，化学的な種々のガスや液体の測定が直接坑井内で行な われるわけである。化学的な測定の場合に注意しなければならないことは使用する循環泥水との関係であ る。特に，島の海岸などにほるということになれば，坑井，地層内に滲透してくる海水の塩分のことなど を考えなければならず，この場合は上に述べた電気検層，放射能検層も当然影響を受けることになる。

なお，放射性物質の崩壊生成物質の測定から各層および地球の年代決定も可能となろう。

坑井がすっかり完成してから後は, たとえば坑井内に地震計 (受振器), 磁力計, 温度計その他, 化学 分析用の計器等を入れて半永久的な測定に利用する他, 坑井内の適当な深さで火薬爆発をおこし, 人工地

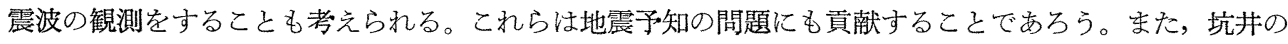
浅い部分から深い部分の相対位置を長年に亘ってしらべることによりマントル内上部の対流をしらべる可 能性もある。

以上と並行して地上へ取り出したコァーによってわ地質, 岩石学的研究と共に種々の地球物理, 地球化 学的研究を行なうことができる。ところで,ここに問題なのは, 坑井内において, つまり高温, 高圧下の 液体中において酎水, 耐圧, 耐熱, 絶緑などのことを考虑した場合, 以上の如き測定が行なえる器械, お よび地上からつるすケーブルワイヤー，キァブタイヤーなどはまだ充分には完成していないのである。從 ってこれらの技術を早急に開発しておくことが必要である。 
一方，これだけ各種の測定を行なうことになれば，お互いに研究計画をよく打ち合わせ，仕事をうまく 進めるためにそれ相応のしっかりした大きなグループなり組織を持つととが是非必要となるものと思われ る。

次に試錐位置の選定ならびに日本の深層試錐計画について述べよう。深層試錐の目標はUMPにおいて はマントル上部にある。従って，この本来の意味からす机ば日本に执いてる何とかして深くほりたい。乙 かしながら，そこには試錐機械の能力と費用といら点からおのずと限度がでてくる。

ここで，こころみにアメリカとソ連の計画に目を向けて見よう。

アメリカではモホロビチック不連続面に試錐の孔をあけるという意味からこれをモホール (Mohole) 計 画と呼えでいるが，National Science Foundation から 170 万ドルの資金を得て 1961 年春に，カス 1 号 により南カリフォルニア沖約 $3700 \mathrm{~km}$ の海底に五つの孔がほられ, その一つは $180 \mathrm{~m}$ に達し, crust 第 二層を通過し, 満足すべき成果它収めた。そこでアメリカではさらに科学アカデミー学術研究会議の AM SOG 委員会が中心になって本格的な Mohole 計画を立てている。くっさく地点の詳細はまだ明らかにさ れてないようであるが，だいたいの地域として 2 カ処，一つは太平洋，他は大西洋で，大西洋の方はプエ ルトリコの北の地域（水深 $5.5 \mathrm{~km}$ ，モ木層の深さ水面より $9.6 \mathrm{~km}$ ），太平洋ではメキシュ沖のガ.ダルー プ (Guadalupe) 島とクリッパートン (Clipperton) 島との間の地域が候補にあがっているようである。 そしてプエルトリコ北方のはすでに着手したようにきいている。

り連の方は Sovmohole 計画としてカスピ海北方，ずっと北のカレリア，それからウラル地方とコーカ サス，そしてずっと東にとえで千島のシコタン島に挄いて 10 乃至 $15 \mathrm{~km}$ の深井戸を計画している。

アメリカの方は海洋からマントル上部を重要視しているが, ソ連の方は主として大陸の陸地で, モ木層 よりはむしろコンラッド面定衫らっている感がある。

そこで日本に課せられた使命を考光てみるに，そ机はUMP 全体の目標が島弧に向けられている。(島 弧の地震, 火山……) 試錐位置選定の場合に，我々としてはこの点を考虑に入れておく必要がある。すな わち, 日本の場合, A, B, C中の何机かの地点がUMP九つのいろいろの調査研究結果から最重要地点 として決められるであらうが，それは何も陸地に限ったことではない。陸地で， $4500 \mathrm{~m}$ 乃至 $5000 \mathrm{~m}$ とい う深さはどうも中途半端な深さになりか叔ない。勿論, 浅くとも, 陸地で非常に大切と思われる地点が元 らばれるかも知れない。しかし，たとえば B 地域のある島がとりあげられることも充分考光られる。

この方がマントルにいくらかでも近づく可能性がある。そしてての場合は火山島であろうから，試錐の 際, 地下坑井内の急激な温度の上昇考慮に入れておかなけ机ばならない。しかし，たと党ば，岩漿溜自 体関係のあるいろいるの状態の分かることが期待される。

ともあれ，日本の場合は，現在，海洋でほるだけの機械は持っていない。とすれば，日本の最上級のく っさく機械は陸上用の National Supply Co.の T-110 型陚錐機である。この機械では，すでに関東地方 (杤木県の春日部で） $3100 \mathrm{~m}$ の石油ガス井戸が掘られている。

仮りにほり管 (drillpipe) は最上級（E級）のものを使用し, casing は $300 \mathrm{~m}$ では $11^{6} / 8$ インチ（又

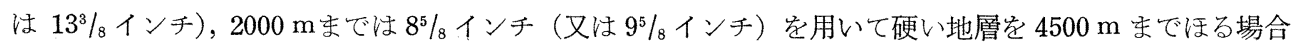
には，準備に 45 日，作孔に 450 日，解体に 30 日，計 525 日（約 1 年半）の日数を要する。

従って, この計画はUMPの他の研究項目とやや趣を異にし, 先程のべたようにこれら研究項目の実施 により判明した結果に基ゔき，深井戸をほるべき場所をきめ，第 2 年目の中頃から着手するととになる。

総経費は現在の物価指数で 4 億 7300 万（坑井内測定を含め）で，UMP総予算額の $44 \%$ に当たる。 担当は地質調查所で，実施は帝国石油株式会社のような石油くっさくの会社となろうが，実施すること が決まれば，先程ものべたように大きな研究グループなり組織が必要となるう。

以上を要するに，この種の計画を実施するのはUMP計画を执いて他にはなく，しかもその重要さから タて，是非とも，この際にとりあげら机実施できるようにしていただきたい。 